inny przebieg niż w ciele ziemskim, bo podlegaja innym prawom, prawom porządku nadprzyrodzonego, zwróconym do celu nadprzyrodzonego.

Kraków

Ks. LUDWIK STEFANIAK C. M.

\title{
SIOSTRA MARIA RENATA A LITURGia
}

Polskich pisarzy katolickich zajmujących się w okresie międzywojennym tematyką liturgiczną - można by wyliczyć na palcah jednej rẹki. A wśród tej małej grupy pisarskiej pierwsze miejsce zajmuje Siostra Maria Renata od Chrystusa, niepokalanka. Jej imię zrosło się nierozerwalnie z polskim ruchem liturgicznym.

Swoją pierwszą znajomość i umiłowanie liturgii S. Renata zawdzięczała pobytowi w zakładzie wychowawczym Sióstr Sacre Coeur w Pradze pod koniec ubiegłego stulecia. Do zakładu tego przychodzili często benedyktyni z opactwa Emaus, odprawiali nabożeństwa i wygłaszali konferencje liturgiczne. Również wychowanice SS. Sacre Coeur chodziły do kościoła opackiego, by uczestniczyć w uroczystych celebrach. Obudzone w ten sposób zainteresowania liturgiczne S. Renata rozwijała $\mathrm{w}$ rozmowach ze swoimi wychowawczyniami, zakonnicami Sacre Coeur, z benedyktynami, którzy udostępnili jej również odpowiednią literaturę.

Największą emocjonalną siłą, która związała S. Renatę z liturgią, był jej półroczny pobyt w Rzymie w 1892 r., przed wstąpieniem do zakonu. Blask nabożeństw w bazylikach, rzymskich, śpiewy gregoriańskie, oficjum brewiarzowe odmawiane w chórach kościołów klasztornych wywołało w umyśle młodej dziewczyny przeświadczenie, że żadna forma pobożności nie jest tak piękna i rozsądna, jak liturgiczna. Zwiedzając miasta we Włoszech i krajach zachodniej Europy, S. Re-

${ }^{20)}$ Estius, s. 775: Ostendit autem haec apostolica adhortandi forma, quam falsum sit ac delirio simile, quod docent hacretici, in bonis operibus non esse respiciendum ad retributionem mercedis a Den propositae. 
nata brała udział w nabożeństwach w takich kościołach, o których wiedziała, że pielęgnuje się w nich ducha liturgii. Jak ten udział był rzeczowy i głęboki świadczy fakt, że do końca swojego życia S. Renata pamiętała poszczególne nabożeństwa i ceremonie liturgiczne w których uczestniczyła w swej przedzakonnej młodości.

„Pamiętam raz $w$ katedrze - było to we Francji - przebrzmiat graduat „Haec dies“, organy nagle urwaty. Cisza zaległa kościót, cisza oczekiwania, prawie że niepokoju; wiedziano, że teraz ma zabrzmieć wielkanocne "Alleluja“. Wtem głos chłopięcy przeszył powietrze, jak srebrna strzała na błe-kicie niebios, $i$ obił się o gotyckie sklepienie. Miało się wrażenie wiosennej czystości, wody źródlanej, przejrzystości kryształu, czegoś świeżego, jasnego, dziewiczego. Nie wim, kim byt ów mały śpiewak boży, ale śpiewat, jak anieli $w$ niebie. W nutę jego wpadty niebawem (na ,iubilus") tamte pacholęta; cała schola rozskowronkowała się i ciagnęła dalej te cudowne neumy, dajac słuchaczom niezapomniane wrażenie wielkiej, prawdziwej, prostej, a głębokiej, jedynie kościelnej muzyki“.

Po wstąpieniu do zgromadzenia Sióstr Niepokalanego Poczęcia, S. Renata nie miała możności brania udziału w liturgicznej służbie bożej poza kaplicą klasztorną, ale znalazła więcej sposobności do zaznajomienia się z księgami liturgicznymi i podstawową literaturą liturgiczną. Nie rozstawała się z mszałem i brewiarzem, a treść tych ksiąg była tematem jej codziennych rozmyślań i źródłem ciągłych zachwytów. Studiowała rytuał i pontyfikał rzymski, ceremoniał biskupi, antyfonarz, kancjonał itp. i na tych dziełach powiększała i kształciła swoją wiedzę liturgiczną. Uzupełniała ją dziełami najlepszych piór, w których rozczytywała się ze smakiem i znawstwem.

Zawsze ulubioną lekturą był „L'annee liturgique“ - Guerangera, "Liber sacramentorum" - Schustera, „Das Jahr des Heiles", Parscha. Miała wielkie uznanie dla prac O. Flicoteaux OSB., Lefebure OSB., O. Grea OSB, O. Morin OSB, O. Marmion OSB., O. Hugon O. P., O. van Oost OSB, ks. Kordela, ks. Nowackiego, Swietlickiego, Quardini. - S. Renata czytała stale krajową i zagraniczną publicystykę liturgiczną, trzymała rękę na pulsie ogólnokościelnego życia liturgicznego 
przez osobiste i listowne kontakty z pracownikami apostolstwa liturgicznego.

Dzieliła się z drugimi swoją myślą i uczuciem ukształtowanym pod wpływem liturgii - według dominikańskiej maksymy: „Contemplata aliis tradere“ w dwojaki sposób: Przez nauczanie, oraz przez pisane słowo.

Pracę nauczycielską miała ułatwioną dzięki temu, że w 1901 r. Wstapiła do zgromadzenia Sióstr Niepokalanego Poczęcia w Jazłowcu.

Program nauczania w Jazłowcu nie obejmował jakichś specjalnych wykładów liturgicznych, ale S. Renata umiałá nawet na lekcjach języków obcych, które prowadziła, poruszać tematykę liturgiczną. Swobodniej już mogła mówić o liturgii podczas pogadanek wychowawczych, prowadzonych poza programem nauczania, a także w czasie rekreacji, w których brała udział razem z uczennicami. W bezpośrednich rozmowach, pogawędkach, opowiadaniach, wspomnieniach umiejętnie skierowywała zainteresowania i sympatie wychowanek. w stronę liturgii. Gdy pomyśli się z iloma dziewczynami S. Renata stykała się w ciągu swojej długiej pracy nauczycielskiej, to wtedy łatwiej wyobrazić sobie skutki jej liturgicznego apostolstwa. Wychowanki jazłowieckie, a później również wychowanki innych zakładów SS. Niepokalanek w Polsce, opuszczały internat, szły w świat, zakładały swoje rodziny i wszczepiały swoim mężom i dzieciom liturgiczną pobożność, jakiej nauczyła ich S. Renata. W ten sposób S. Renata przez tysiące swoich wychowanek dotarła do dziesiątków tysięcy polskich katolików.

W Jazłowcu znajdował się nowicjat zakonny. S. Renata miewała również dla nowicjuszek wykłady o liturgii, a w latach późniejszych w innych domach zgromadzenia takie same wyłkłady dla młodszych sióstr.

Rzecz jasna, że jej praca publicystyczna miała znacznie szerszy oddźwięk. S. Renata rozpoczęła swoją prace pisarska. od artykułów zamieszczanych od 1929 r. w takich czasopismach polskich, jak: „Hosanna“, „Pro Christo“, „Mysterium. Christi", „Szkoła chrystusowa", oraz w zagranicznych. Z biegiem lat prawie wszystkie polskie pisma katolickie drukowały 
prace S. Renaty, a zagranicą belgijski ,Bulletin Paroissial Liturgique" najchętniej zamieszczał jej artykuły. Forma artykułu, krótkiej rozprawy, esseju pozostawał na zawsze ulubianym sposobem wypowiadania się S. Renaty. Jej późniejsze książki są zawsze zbiorem krótkich utworów ułożonym stosownie do treści tytułu. Pióro S. Renaty działało sprawnie. Umiała nim przelać na papier swoje zdolności narracyjne. I dlatego utwory S. Renaty sa pozbawione nudy. Tego najczęstszego niebezpieczeństwa, jakie czycha na pisarzy liturgicznych. S. Renata nie gubi się w szczegółach, nie zatraca rytmu sekwencji w komentatorskich dłużyznach, język ma żywy, styl zwarty i przejrzysty. Zaleta wykładu S. Renaty jest jego poglądowość i brak przeładowania.

Cel działalności S. Renaty na polu liturgicznym był podwójny. Po pierwsze - gruntowne zaznajomienie społeczeństwa polskiegozliturgią katolicka, po drugie - wykazanie, że liturgia ta jest pię kna.

Trzeba było zaczynać od podștaw. Przybliżyć księgi liturgiczne wiernym. Przetłumaczyć je. Pierwszy polsko-łaciński „Mszal rzymski z dodatkiem nabożenstw nieszpornych" wydali benedyktyni belgijscy $z$ opactwa św. Andrzeja przy współpracy SS. Niepokalanek. Zgromadzenie, w którym działała S. Renata dokonało tej pionierskiej pracy. Teksty liturgiczne domagają się jednak obszernego komentarza. Spieszy z nim S. Renata w swoich wykładach i artykułach. Kreśli historię mszału, rozwój Mszy św., omawia poszczególne teksty mszalne. Niezmienne i zmienne. Omawia dokładnie trzy Msze św. Narodzenia Pańskiego, Mszę św. wielkanocną, Zielonych Swwiąt, Msze św. w uroczystości Pańskie, Bożej Rodzicielki i Świętych Pańskich. Swój obszerny komentarz do tekstów mszalnych tych świąt wydaje w książce ,Sladami tajemnic Chrystusowych“2). S. Renata podkreśla zarazem, że Msza św. liturgicznie pojęta, to Msza śpiewana, msza, w której głos kapłana łączy się ze śpiewem wiernych. I tu trzeba wyjaśnić -

$\left.{ }^{1}\right)$ Por. S. M. Renata, Sentire cum Ecclesia, Poznań 1931, s. 183n.

2) Wyd. Centrali Milicji Niepokalanej, Niepokalanów 1949. 
co to jest śpiew kościelny, śpiew gregoriański. Autorka książki „Sentire cum Ecclesia“. robi to ze znawstwem. Plastycznie tłumaczy znaczenie i wartość śpiewu liturgicznego w czasie Mszy św.

Nie wystarczy jednak posiadać i rozumieć mszał. W ,Sentire cum Ecclesia“ S. Renata pisze: „trzeba umieć go używać. Nie myśle tu o orientowaniu sie $w$ jego podziale, w jego odsyłaczach itd. - to rzecz wprawy $i w$ niedługim czasie kazdy się tego nauczy. Ale o co innego, znacznie ważniejszego tu chodzi: chcac dobrze używać mszału, chcac karmić nim dusze, a dać pobożności swojej, silna, granitowa podstawa, trzeba mszał przemedytować. Najlepiej $z$ wieczora, przed udaniem się na spoczynek, odczytać sobie uważnie zmienne części Mszy św., przypadajacej.na nastepny dzień, wraz z odnośnymi komentarzami, pozakładać wszystko, aby sie nazajutrz w czasie Mszy św. nie ,zgubic" ", szukajac w odsyłaczach, podczas. gdy kapłan przy ottarzu idzie dalej. Następnie przede Msza, w kościele, czy kaplicy, rozważyć głębiej, co się wczoraj przeczytało, starać się wniknać $w$ tekst święty, zastosować go do swoich trudności, czy potrzeb $i$ wejdziemy nieposirzeżenie $w$ modlitwę: serce nasze się rozpali, umysł nasz się oświeci, wola zmężnieje i zapomnimy o świecie, - stanie przed nami On, Umiłowany, Jedyny, ze światłem swoim, z moca swoja, $z$ miłościa swoja, - On, Stowo Przedwieczne pod postacia. Słowa" $\left.{ }^{3}\right)$.

Przed drzwiami kaplic SS. Niepokalanek S. Renata umieszczała wywieszki inormujące o liturgii danego dnia i objaśniające Mszę św. W czasie Mszy św. recytowanych osobiście dbała o to, aby każdy z uczestników miał przed sobą właściwy tekst.

Po zbliżeniu do wiernych mszału rzymskiego, S. Renata udostępniła im również zrozumienie brewiarža. Chciała, aby brewiarz był księgą modlitw nie tylko osób duchownych, ale również świeckich. „Mszał $i$ brewiarz nie sa przęnaczone wyłacznie dla kapłanów i $w$ pierwszych wiekach chrześcijaństwa znáne one były $i$ wiernym. Kaptani sa, rozumie się, pośredni-

s) Por. d. c., s. 27. 
kami pomiędzy niebem, a ziemia, szafarzami łask bożych dla ludu, ofiarnikami $w$ imieniu Chrystusa, jedynego najwyższego Kapałana ,secundum ordinem Melchisedech". Ale i wierni maja pewien udział $w$ tym kapłaństwie: wszak jesteśmy ,genus electum, populus acqisitionis, gens sancta, regale sacerdotium". Kościót zamkną $w$ tych księgach liturgicznych najpiękniejsze swe modty, najwznioślejsze hymny, cały dogmat i cata etykę: lex orandi - lex credendi, a dodać by można: lex credendi - lex vivendi. Długo, zbyt długo byty one ogrodem zamknietym ,hortus conclusus“. Niech otworza swe karty; ,niech popłyna wonności“; niech nakarmia łaknacych, niech napoja spragnionych. "Tolle, lege“ bierzmy i czytajmy $i$ wczytujmy sie $i$ rozczytujmy się. Uczmy się z tych ksiag świętych czuć, myśleć, sadzić z Kościołem, śpiewać jak on, modlić się, jak on, kochać, jak on, stowem: sentire cum Ecclesia" $\left.{ }^{4}\right)$.

Poczynając od elementarnego wykładu o histori i układzie brewiarza, S. Renata w kilku rozdziałach, ,Sentire cum Ecclesia“ i „Vivere cum Ecclesia“"5) omawia wnikliwie poszczególne części składowe godzin kanonicznych, jak psalmy, antyfony, hymny, lekcje, responsoria, posługując się zawsze swoim obrazowym językiem. Oto np. w ten sposób pisze m. inn. o responsoriach z jutrzni: „Wyrażaja one odgłos wywołany $w$ duszy przez poprzedzajaca lekcje brewiarzowa. Faluja. $w$ nich myśli $i$ obrazy i uczucia, splataja się, wynurzaja i znikaja, by za chwile znów się odezwać dalszym, słabnacym echem. Na pierwszy rzut oka to powtarzanie i powracanie tego samego motywu wydać się może arbitralnym, przypadkowym. Dusza odpowiada na stowo pańskie samorzutnie, bez rozmysłu, bezplanowo, - tak jak myśl w mózgu naszym jedna po drugiej następuje, a uczucie $w$ sercu naszym to wznosi się, to opada. Ale $i$ tu, jak $w$ naturze, wszystko dzieje sie wedtug pewnych, nieodmiennych praw: wszak przyptyw $i$ odpływ, szum $i$ huk .morskich bałwanów maja swe stałe $i$ nienaru-

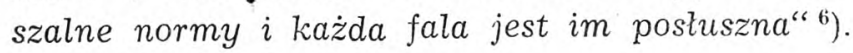

$\left.{ }^{4}\right)$ Por. d.c., s. 2 n.

5) Wyd. OO. Karmelitów Bosych, Kraków 1948-49.

c) Por. d c., s. 57. 
S. Renata sama przeprowadzała rozmyślanie, opierając się na brewiarzu i wzorem liturgistów zachodnich zachęcała swoich czytelników, aby „officium divinum - było dla nich źródłem $i$ metoda rozmyślania". Nad brewiarzem bowiem można odbyć, właściwe dla prawidłowego rozmyślania ćwiczenie rozumu i pamięci, które rozbierają tekst, aby nim się karmić, wzbudzanie uczuć, które się wylewają w duchowej rozmowie, postanowienie, jako akt woli wypływający z rozmyślania, wreszcie wiązanka duchowa, gdy jakieś rano zasłyszane słowo liturgiczne rozbrzmiewa w duszy przez cały dzień, jako motyw przewodni towarzyszący jej pracom i zajęciom i opromieniający je swą boską poezją.

Oprócz mszału i brewiarza, katolik powinien dobrze znać i rozumieć sakramenta św., które dają mu uczestnictwo w życiu bożym. Często zdarza się, że sakramentalne signa visibilia są jeđnocześnie znakami niezrozumiałymi, uchodzącymi w oczach niewykształconych wiernych za rodzaj praktyk szamańskich. S. Renata poświęciła wyjaśnieniu liturgicznej strony sakramentów św. całą swoją książkę ,U źródeł ła$s k i{ }^{* 7}$ ). Praca ta pozostała daleko od suchego komentarza do rubryk rytuału rzymskiego, jakim mogła się stać, przedstawiła natomiast obrzędy sakramentalne w sposób żywy i obrazowy na szerokim tle historyczno-kulturalnym.

Charakterystyczną cechą wykładu S. Renaty była, jak wspomniałem, poglądowość. Posługiwała się tą metodą umiejętnie i z przyjemnością. Karty „U źródeł taski" zatrzymały może najlepiej poglądowy wykład liturgiczny S. Renaty. Tak np. brzmi opis uroczystości Wielkiej Soboty w bazylice św. Jana na Lateranie, zawierających w sobie chrzest katechumenów: ,Wigilia wielkosobatnia zaczynała się o zachodzie słońca. Wyobraźmy sobie, że jesteśmy np. w bazylice św. Jana Lateraneńskiego $w$ Rzymie, w IV lub $V$ wieku. Ogromna światynia $z$ dzielacym ja na trzy nawy lasem kolumn tonie $w$ mrokach wieczornych. Ostatnie promienie zachodu. igraja $w$ złocistych mozaikach absydy. Lud zebrat sie ttumnie na, ,wigilię"w te prawdziwie, ,Wielka Noc", która poprzedza Zmar-

7) Wyd. N. I. A. K., Poznań 1937 r. 
twychwstanie Pańskie. Już stońce zapada za wzgórze Janiculum, a biskup $w$ otoczeniu duchowieństwa udaje się pod. portyk bazyliki, gdzie studzy światyni krzesza nowy ogień $z$ krzemienia - symbol Chrystusa zmartwychwstajacego. Błogostawi go w pięknych, prastarych modlitwach $i$ wnosi uroczyście do kościoła, przy trzykrotnym śpiewie „Lumen Christi" - świattość chrystusowa - na który obecni odpowiadaja radośnie: Bogu dzięki — „Deo gratias“.. „Dziś wo- bec ustania praktyki chrztu dla dorosłych i przesunięcia, od XI wieku, tej Mszy na sobote rano, cata liturgia Wielko-sobotnia stała się trudna do zrozumienia. Bowiem po tej krótkiej wielkanocnej radości wracamy do ziwiedzania „Grobów“, do kilekotek $i$ żałobnych nastrojów..." ${ }^{8}$ ) A tak rozpoczyna się rozdział o Chrzcie św.: „Podwoj̈e światyni Panskiej stanęty otworem na przyjęcie orszaku wstęujacego po stopniach doń prowadzacych: to niosa nowonarodzone dzieciatko do odradzającego zdroju chrztu św. Nie domyśla się ono wcale jak ważna $i$ uroczysta przeżywa chwile, ale pograżone $w$ nieświadomości śpi na ręku troskliwej matki chrzestnej"9).

Poglądowe spojrzenie na sakrament pokuty S. Renata zaczerpnęła z Boskiej komedii. Po zacytowaniu kilku tercyn „Czyśćca" pisze: „Wszystko to symbolizuje sakrament pokuty i główne warunki jego. Najpierw rachunek sumienia, to stopień marmurowy, wypolerowany, jak lustro, które wiernie odbija obraz przegladajacego się $w$ nim. Potem żal za grzechy, zawierajacy $w$ sobie mocne postanowienie poprawy, to kamień czarny, jakby skruszony i popelkany od zaru. Wreszcie zadośćuczynienie $w$ zastugach Krwi Chrystusowej: to purpurowy porfir, z którego bierze takize moc i absolucja sakramentalna. Dlatego anioł, figura kapłana, trzyma stopy oparte na nim. Siedzi zaś na diamentowym progu przebaczajacej mitości i odziany jest szaro, na znak pokory $i$ umartwienia" ${ }^{10}$ ).

Życie liturgią nie powinno się, według S. Renaty, ograniczać do świąt i uroczystości. Tak jak życie ziemskie składa się

$\left.{ }^{8}\right)$ Por. d. c., s. 25. 32 .

9) Por. d. c., s. 16.

$\left.{ }^{10}\right)$ Por. d. c., s. 102n. 
z nieprzerwanego ciągu dni, tak i życie duchem liturgii musì trwać stale. Musi składać się z całego cyklu lat liturgicznych, następujących bez przerwy po sobie'. Wciągnięcie katolickiego społeczeństwa polskiego w zrozumienie i ukochanie roku liturgicznego było kolejnym zadaniem S. Renaty. Wierzyła, że kto pojmie i pokocha rok liturgiczny, będzie nim żyć, a tym samym zacznie żyć z Kościołem: „Vivere cum Ecclesia". Taki też tytuł dała swej pracy o roku liturgicznym. Pisze tam we wstępie: „Jeżeli liturgia jest konieczna funkcja życiowa $M i_{-}$ stycznego Ciała Chrystusowego, tak jak modlitwa oddychaniem duszy, rok liturgiczny przeksztatca Piusowe hasto ,Sentire cum Ecclesia“ na ,Vivere cum Ecclesia“. „Czy nie stusznie można nazwać rok liturgiczny „Corona benignitatis annì Dei"? Czyż nie jest on $w$ całym tego słowa znaczeniu ,wieńcem dobrotliwości roku Bożego"? Jak bowiem obrót ziemi dokoła sprawia kolejność zimy i lata, wiosny $i$ jesieni, które składaja się na rok ziemski, - tak rok liturgiczny, cudownie urozmaicony kolejnym nastẹpstwem świąt $i$ okresów światecznych, $w$ niewyczerpanym bogactwie niezrównanego piękna, wywołany jest nieustannym krązeniem myśli $i$ serca Kościoła dookoła Chrystusa w Jego tajemnicach, tego wiekuistego „Słońca sprawiedliwości“, które nam świta w Adwencie, wschodzi na Boże Narodzenie, świeci prawda i miłościa w okresie „per annum“, ćmi się w Wielkim Poście, zachodzi na Kalwarii wśród ciemności wielkopiątkowych, aby wzejść na nowo $w$ triumfalnym blasku $w$ dzień radosny Zmartwychwstania" $\left.{ }^{11}\right)$.

Być może, że czytelnikowi nie przejętemu jeszcze rytmem życia liturgicznego, trzeba było dać w ,Vivere cum Ecclesia“ bliższe i bardzie praktyczne wskazówki normowania jego codziennych zajęć według liturgii dnia. Możliwe jest jednak, że S. Renata celowo pominęła tę dziedzinę z uwagi na tłumaczenie dzieła O. Baura OSB. „Werde Licht“, które przygotowywało Zgromadzenie Sióstr Niepokalanego Poczęcia. Poprzestała na przetykaniu rozważań o roku liturgicznym refleksami w rodzaju myśli jakie nasunęło jej postcommunio ze Mszy św.

11) Por. d. c., s. 2. 18. 
na Zwiastowanie NMP. ,Na zwiastowanie anielskie pada juz cień kalwaryjskiego krzyża, ale jednocześnie różowi się $w$ oddali świt Zmartwychwștania... Tak i w naszym życiu: zorza. powotania - ogólnego do wiary, przy Chrzcie świętym, dla niektórych szczególnego do bliższego stosunku z Bogiem w stużbie ottarzá lub przez śluby zakonne. - Skwar znojnego południa, męka i krzyż, trud $i$ upracowanie, krew $i$ łzy serdeczne. $\mathrm{Na}$ koniec wieczysta nagroda $w$ niebie, w której cały człowiek, $z$ dusza nieśmiertelna i wskrzeszonym ciałem udział mieć będzie ad resurrectionis gloriam perducamur" ${ }^{12}$ ).

Określając dwa cele, ku którym kierowała się liturgiczna działalność S. Renaty, na pierwszym miejscu wymieniłem zaznajomienie katolickiego społeczeństwa polskiego z liturgia, a na drugim ukazanie mu, że liturgia jest piękna. Takie usytụowanie wydawało się mi logiczne. Ale gdy się uważnie czyta wszystko, co wyszło spod pióra S. Renaty z łatwością można spostrzec, że cel, według mnie wtórny, najjaśniej świecił przed oczami S. Renaty i występował na pierwszym planie.

Autorka „Liturgii a sztuki" była niezmiernie wrażliwa na piękno i sztukę, w jakiejkolwiek by się ona objawiała postaci. Jej wychowanie, jakie otrzymała w domu rodzinnym i pensjonatach zakonnych uwzględniało mocno element estetyczny, co $\mathrm{w}$ połączeniu $\mathrm{z}$ wrodzonymi zamiłowaniami wykształciło. u S. Renaty wyjątkowe zrozumienie i odczucie sztuki. W liturgii S. Renata widziała przede wszystkim niezgłębione i niewyczerpane skarby piękna. Można by zaryzykować twierdzenie, że gdyby liturgia katolicka nie była szczególnie piękna, nie miałaby swej gorącej apostołki w osobie S. Renaty. Najbardziej typowe dla jej twórczości sa te sekwencje jej dzieł, które podkreślają stronę estetyczną modlitw, ceremonii i obrzędów katolickich. „Kraina liturgii, to kraina cudów, czarowna pięknem nadziemskim, pięknem tak mało znanym, a niekiedy tak zapoznanym. To ogród zamkniony, zdrój zapieczętowany dla wielu. Takby si€̨ chciało wrota tego raju otworzyć naścieżaj, strumienie tej wody żywej udostępnić wszystkim spragnionym: Omnes sitientes, venite ad aquas. W tym

$\left.{ }^{12}\right)$ Por. d. c., s. 358. 
cudnym ogrodzie przechadzać się można $z$ rozkosza. Sa tam szczyty, z których roztacza się widok daleki, sięgajacy aż po wzgórza wiekuiste, sa tam ustronne doliny, w których kwitna kwiaty o barwach najrzadszych, $i$ o przedziwnej woni. Sa tajemricze groty, w których się żarza zaklęte $w$ stowo skarby. Sa cieniste aleje, sadzone wersetami niebotycznych psalmów, $i$ jasne polany lekcji brewiarzowych, sa łaki umajone wonnymi antyfonami i ptynace rytmiczna melodia srebrzyste strumyki hymnów ${ }^{13}$ ).

Mszał, uczy S. Renata za Dantem, ,poemat święty, do którego przyłożyty reki $i$ niebo $i$ ziemia". On uczy ,modlić sie na pięknie", według określenia Piusa X. Aby ocenić całą piękność struktury brewiarza, trzeba pamiętać, że właściwie brewiarz jest modlitwą chórową, wspólną, po części śpiewaną przypomina S. Renata. „Chcac mieć jakiekolwiek pojęcie o jego artystycznej wartości (pomijajac treściowa) trzeba by posłuchać, jak go śpiewaja Benedyktyni lub Benedyktynki, trzymajacy się autentycznej interpretacji gregoriańskiego śpiewu, przywróconej przez uczone prace opactwa solesmeńskiego we Francji. Zreszta, nie szukajac tak daleko, postuchajmy kiedy autentycznych gregorianskich nieszporów, albo wieczornej komplety $w$ tych kościołach lub klasztorych kaplicah (niestety jeszcze bardzo nielicznych w naszym kraju) gdzie śpiew gregoriański się przyjąt, a z pietyzmem, zrozumieniem i miłościa jest pielegnowany. Niezawodnie ulegniemy jego boskiemu czarowi" $\left.{ }^{14}\right)$.

Gregoriańska psalmodia brewiarzowa nie pozwala S. Renacie przejść obojętnie wobec swoich melodii. ,Niech będzie wolno powiedzieć tylko stńwko o niezrównanej piękności tej muzyki, najprostszej, jaka być może, bo złożonej z kilku wciaż powracajacych tonów, a jednocześnie najgłębszej $i$ najsubtelniejszej. Te wersety nastęujace po sobie regularnym rytmem, wzbierajace $i$ opadajace jak fale spokojnego morza, które tocza sie majestatycznie ku ladowi, uwieńczone piana - i kłada się cicho, jedna po drugiej, na złotym piasku wybrzeza - czynia olbrzymie wrażenie. Któż nie wie, że wielki Augustyn, jeszcze przed nawróceniem, z nieopisanym wzruszeniem przy-

13) Por. d. c., s. 14.

14) Por. d. c., s. 22. 
stuchiwał się psalmodii, świeżo zorganizowanej w kościele mediclańskim przez św. Ambrożego, psalmodii w której brali udział nie tylko kantorzy, ale caty ttum wiernych $w$ gromadzie, dla wzajemnej pociechy $i$ nauki. Kiedyzi $i$ nas tak bedzie? 'Kiedyż nieszpory, autentyczne tacińskie nieszpory, uwieńczone cudna modlitwa wieczorna Kościoła, kompleta, stana sie, jak to jest we Francji, Belgii, lub Włoszech, naturalnym dopetnieniem dnia niedzielnego?" ${ }^{15}$ ).

W responsoriach, sa zaklęte całe światy poezji i piękna". „gdy tak przebiegniemy te wspaniate utwory liryczne, których muzyczna szata godna jest poetyckiej treści, gdy rzycimy pobieznie tylko spojrzenie na te bogactwa nieprzebrane, które zawiera jeden tylko dział brewiarza, możemy się zapytać: gdzie i kiedy nagromadzono podobne skarby poezji i melodii? I przyjdzie nam tylko dziękować Bogu, Trójcy wszelkiego piękna, Pięknu niestworzonemu, iż nas przez Kościóz św. tak hojnie obdarzyt, iz zaspokoit gtód naszych dusz ta. Pięknościa zawsze dawna, a zawsze nowa $i$ dał nam ku śpiewaniu chwaty swojej pieśń godna siebie - carmen Deo nostro $\left.{ }^{16}\right)$.

I tak jest w każdej pracy S. Renaty. Nieomal w każdym zdaniu, które czerpie z liturgii piękno i każe czytelnikowi podziwiać je. Obrzędy sakramentalne są pełne znaczenia, ale przede wszystkim są piękne. W treści świąt kościelnych mieści się prawda wiary, ale także prawda piękna. Rok liturgiczny to sposób mocy na żywot wieczny, który dociera do nas nieprzerwanym korowodem piękna.

Szczególniejszą miłością, jak już wspomniałem, darzy S. Renata piękno śpiewu gregoriańskiego. Korzysta z każdej sposobności, aby o nim mówić i uczyć go. Zgromadzenie Sióstr Niepokalanego Poczęcia pod wpływem S. Renaty i ks. Nowackiego pielegnuje u siebie i propaguje śpiew gregoriański, wytwarzając u swoich wychowanek świadomość, że Msza śpiewana, właściwie wykonana, jest synonimem Mszy gregoriańskiej. Liturgiczny śpiew gregoriański daje S. Renacie nie tylko najwyższe doznania muzyczne, ale rozwija przed jej oczami akcję dramatyczną.

$\left.{ }^{15}\right)$ Por. d. c., s. 44.

16) Por. d. c., s. 66. 
Literacką interpretację melodii gregoriańskich S. Renata podawał swoim czytelnikom najprawdopodobniej dlatego, ponieważ zdawała sobie sprawę, że śpiew gregoriański nie jest łatwy i trzeba jego melodię zaopatrzyć elementem do pewnego stopnia wizualnym, aby ułatwić jego przyswojenie wiernym nieposiadającym odpowiedniego przygotowania muzycznego.

S. Renata umiała i chciała patrzyć na sztukę przez pryzmat. liturgii. Podobnie, jak na liturgię patrzyła poprzez sztukę. We wstępie do "Liturgii a sztuki“, która to praca jest charakterystyczna dla zainteresowań S. Renaty, czytamy: „Kościót jest matka $i$ piastunka nowożytnej kultury, ceni $i$ pielęgnuje. sztuke, ale jednocześnie czuwa, aby ona nie zeszła na manowce, aby nie byta sama sobie celem i bożyszczem (sztuka dla. sztuki), ale aby, jak filozofia jest, ancilla theologiae", tak ona stała się „ancilla liturgiae“. Sztuka w służbie liturgii stworzyła swe najwspanialsze arcydzieła: od katedr gotyckich w Chartres, Kolonii lub Toledo - do „Requiem“ Mozarta, lub „Improperiów“ Palestriny. Od Boskiej komedii Dantego do Ostatniej wieczerzy Leonarda da Vinci lub malowideł ściennych J. H. Rosena w katedrze ormiańskiej we Lwowie. Kościół kocha Piękno, bo ono jest rodem $z$ nieba ${ }^{17}$ ).

Nie ma rodzaju twórczości, w której S. Renata nie odnalazłaby inspirujących wpływów katolicyzmu i jego liturgii. A robiąc swoje poszukiwania, nie może ukryć radości, że prowadzi je w dziedzinie najmilszej i najciekawszej dla siebie. Między wierszami tej książki czỷta się zachętę, by pójść jej śladem. Zgłębić sztukę, aby znaleźć w niej piękno boże, a w nim odkryć pierwiastki liturgii.

Jeżeli obserwujemy dzisiaj w Polsce większe niż przed laty zainteresowanie liturgią, jeżeli ktoś, trzymający mszalik w ręce podczas Mszy św. nie wzbudza zdziwienia, jeżeli inteligencja katolicka wie, że liturgia Kościoła jest czymś pięknym, jeżeli w końcu są u nas ludzie, dla których poranna Msza św. jest koniecznym i głównym akcentem całego dnia to nie mała w tým zasługa $\mathrm{S}$. Renaty, zakonnicy, kłóra sama umiała żyć pięknem liturgii i uczyć tego drugich.

Nowy Sącz K.S. LESEAW JEŹOWSKI

17) Por. S. M. Renata, Liturgia a sztuka, Poznań 1934, s VIT 